\title{
Reefs as contributors to diversity of epiphytic macroalgae assemblages in seagrass meadows
}

\author{
B. R. Van Elven ${ }^{1}$, P. S. Lavery ${ }^{1, *}$, G. A. Kendrick ${ }^{2}$ \\ ${ }^{1}$ Centre for Ecosystem Management, Edith Cowan University, Joondalup, Western Australia 6027, Australia \\ ${ }^{2}$ Department of Botany, The University of Western Australia, 35 Stirling Highway, Crawley, Western Australia 6009, Australia
}

\begin{abstract}
The links between macroalgae-covered reefs and diversity and biomass of epiphytic algae assemblages in adjacent seagrass meadows were investigated. Algae assemblages were sampled in 3 habitats: on-reef, seagrass meadow near-reef $(<20 \mathrm{~m}$ from reef), and seagrass meadow distant-from-reef $(>3000 \mathrm{~m})$, off the coast of Fremantle, Western Australia. We interpreted differences among these habitats as evidence that proximity to reefs influences epiphytic algae assemblages. Propagules in the water column, epiphytes recruiting onto artificial seagrass units (ASU) and assemblages on natural Posidonia sinuosa were sampled in each habitat. For propagules, ASU and natural $P$. sinuosa, there were significant differences in the structure of algae assemblages near and distant from reefs, while assemblages near reefs tended to resemble those found on reefs. Multivariate analysis (ANOSIM) confirmed that propagule assemblages near reefs and on reefs were similar, but those distant from reefs differed from those on reefs. Near-reef habitat recorded the highest total number of algal taxa growing on ASU (53), followed by on-reef (44) and distant-from-reef (37) habitats. ANOSIM again confirmed that assemblages at on- and near-reef sites were not significantly different, but both differed from those at sites distant from reef. We identified 59 species of algal epiphytes growing on mature $P$. sinuosa leaves at near-reef and distant-from-reef sites, with only 19 species being common to both habitats, and multivariate analyses were suggestive of differences in assemblage structure. Biomass was only recorded for the ASU epiphyte assemblages and was greatest in the near-reef habitat $\left(0.63 \pm 0.11 \mathrm{~g} \mathrm{shoot}^{-1}\right)$ followed by the on-reef habitat and the distantfrom-reef habitat $\left(0.18 \pm 0.04\right.$ and $0.11 \pm 0.01 \mathrm{~g} \mathrm{shoot}^{-1}$, respectively). Our results demonstrate that diversity and biomass of macroalgae epiphytes in seagrass ecosystems differ between habitats of varying proximity to reefs.
\end{abstract}

KEY WORDS: Seagrass $\cdot$ Epiphytes $\cdot$ Diversity $\cdot$ Posidonia sinuosa $\cdot$ Reef $\cdot$ Western Australia Resale or republication not permitted without written consent of the publisher

\section{INTRODUCTION}

Algal epiphytes have long been recognised as a significant component of both the biodiversity and ecological function of seagrass habitats. In addition to typically being species-rich (Kendrick \& Burt 1997) they can be important contributors to primary production and a major source of food for grazers and detritivors in seagrass ecosystems (Kitting et al. 1984, Borowitzka \& Lethbridge 1989). However, neither epiphyte biomass nor diversity is evenly distributed across seagrass meadows, and the nature of spatial variability within meadows can vary among seagrass species (Vanderk- lift \& Lavery 2000, Lavery \& Vanderklift 2002). Edgar \& Robertson (1992) previously showed that mobile epifauna responded in a variety of ways to the presence of epiphytes. This patchiness in both algal epiphytes and species that interact with them suggests that both diversity and ecological function will be patchy within seagrass ecosystems.

Despite their recognised importance, little is known of the processes influencing algal epiphyte diversity in seagrass ecosystems (Kendrick et al. 1988, Borowitzka \& Lethbridge 1989, Lavery \& Vanderklift 2002). It has been hypothesised that reef systems comprise a source for diversity to algal epiphyte assemblages in adjacent 
seagrass meadows (Borowitzka \& Lethbridge 1989, West 1990). The basis of this hypothesis is that reefs have the potential to influence many of the factors known to influence algal diversity. The algal epiphyte assemblage present in a seagrass meadow is the result of many processes, including those related to lifecycles (such as propagule release, dispersal, settlement, germination and growth to the adult stage) and environmental factors such as water motion, nutrient availability and grazing. These factors can act either pre- or post-recruitment and at local or regional scales. For example, the source of propagules may be the seagrass meadow itself (local) or propagules arriving from outside the seagrass meadow (regional), such as adjacent reef systems. Most available information would suggest that local recruitment is likely to be the major source of recruits to seagrass meadows (Lavery \& Vanderklift 2002), and this may be related to the limited ranges of propagule dispersal and survival for many species of algae (Hoffmann 1987, Kendrick \& Walker 1995). For example, less than $0.0001 \%$ of Sargassum spp. recruits survive for 12 mo and their dispersal range is only 1 to $2 \mathrm{~m}$ (Kendrick \& Walker 1995). Thus, in Sargassum spp.-dominated assemblages, local recruitment processes are likely to be more important in maintaining algal epiphyte diversity in seagrasses than regional processes. However, many seagrass meadows occur adjacent to reefs with diverse algae assemblages, and it is possible that these may act as both sources of propagules and as modifiers of the physical and nutrient conditions in adjacent areas.

This study was designed to examine the influence of reefs on the diversity of epiphytic algae assemblages in nearby Posidonia sinuosa meadows, and to determine whether this influence occurs at pre-recruitment or post-recruitment phases of assemblage formation. Due to the nature of the questions and the spatial scales involved, it was impossible to establish an experiment that formally tested the hypothesis that reefs influence algal diversity in seagrass meadows. However, if reefs do influence the diversity of epiphyte assemblages on nearby seagrasses, then algae assemblages on reefs should be more similar to those in seagrass meadows near reefs than those distant from reefs. We specifically examined epiphytic algae assemblages in seagrass meadows at differing proximities to reefs. Further, by characterising the assemblages of algal propagules, early recruitment and the mature assemblages at increasing distance from reefs, we were able to draw conclusions as to whether any influence of reefs on diversity occurs predominantly at the pre- or post-recruitment stage.

\section{MATERIALS AND METHODS}

Study area. The study was conducted off the coast of Fremantle, Western Australia (Fig. 1). Parmelia Bank is a shallow $(<10 \mathrm{~m})$, unconsolidated carbonate sand bank approximately $6 \mathrm{~km}$ south-west of Fremantle. Common seagrass species occurring on Parmelia Bank include Posidonia australis, P. coriacea, P. sinuosa, Amphibolis griffithii, Heterozostera tasmanica and Halophila ovalis (Kendrick et al. 2000). The western boundary of the Bank is a chain of limestone reefs and islands. Carnac and Garden Islands are part of this chain and are entirely surrounded by high-relief reef

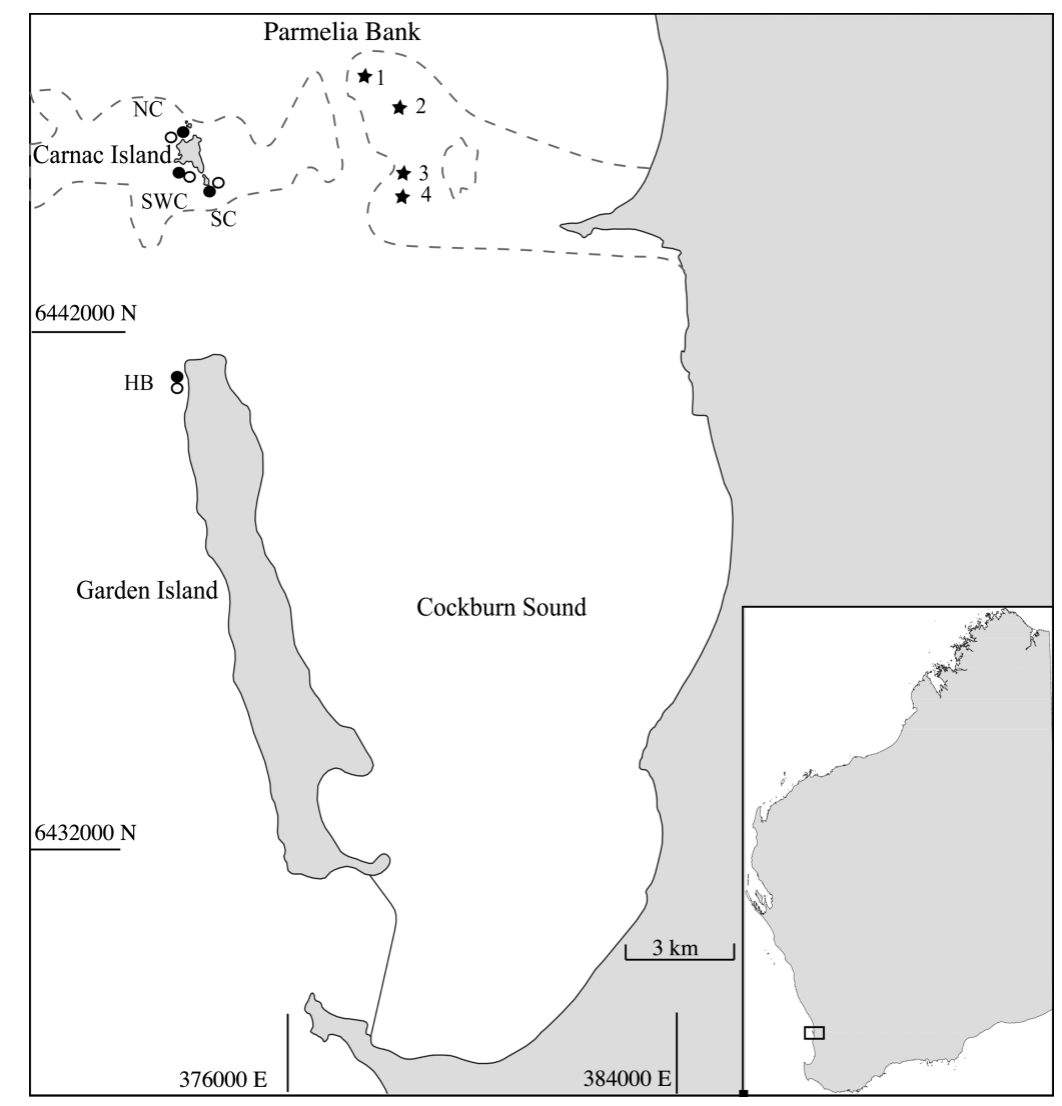

Fig. 1. Location of study sites on Parmelia Bank, Western Australia: (•) on-reef; (O) near-reef; $(\star)$ distant-from-reef. HB: Herring Bay; SWC: south-west of Carnac Island; SC: south of Carnac Island; NC: north of Carnac Island; 1-4: seagrass sites on Parmelia Bank. Dotted lines approximate $10 \mathrm{~m}$ depth contour of Parmelia Bank 
(i.e. reef that is raised more than $0.5 \mathrm{~m}$ above the sediment surface). Thus the Bank comprises an extensive seagrass habitat fringed to the west by a semi-continuous reef system.

Experimental design. We addressed our aim of examining the influence of reefs on epiphytic algal diversity in seagrass meadows through 3 separate tests. At sites of increasing distance from reefs, we tested for (1) significant differences in the availability of algal propagules in the water column, (2) the assemblages of algae that recruited to artificial seagrass at those sites and (3) the assemblages of algae on mature Posidonia sinuosa leaves. In all cases, if the assemblages at sites close to reefs were more similar to those on reefs than were the distant-from-reef assemblages, we interpreted this as evidence that proximity to reefs influences epiphytic algal diversity. Differences in the diversity of algal propagules were interpreted as a prerecruitment influence of proximity to reefs on diversity of epiphytic algae. Species of algae colonising the artificial seagrasses were assumed to reflect those that could successfully recruit on seagrasses during the period of deployment ( 8 to $10 \mathrm{wk}$ ) and differences in these assemblages were viewed as being consistent with an influence of proximity to reef on recruitment. Finally, significant differences in mature epiphytic algae assemblages on $P$. sinuosa leaves were viewed as being consistent with a post-recruitment influence of proximity to reefs on the resultant assemblages of epiphytes. Leaf turnover times for $P$. sinuosa are between 212 and 254 d (Marbà \& Walker 1999), so the oldest leaf would have been available for colonisation 3 to 5 times longer than our deployment of artificial seagrass, and subject to a range of post-recruitment factors such as different hydrodynamic and physical environments that could influence the development of seagrass epiphytes.

The relevant variables were measured/collected from 4 replicate sites within reef ecosystems and from 4 replicate sites near to and distant from the reefs. This provided 3 treatments (on-, near- and distant-fromreef) with 4 replicate sites for each treatment. At each site, 3 replicate samples of algal propagules (for Test 1) and 4 replicate samples of epiphytes recruited onto artificial seagrass or Posidonia sinuosa (for Tests 2 and 3 , respectively) were collected. This sampling design conformed to a nested experimental design, the main factor being proximity to reef (hereafter referred to as 'habitat') and with sites nested within habitat.

The study was not designed as a gradient analysis, which would have required a greater number of distances from reef. Instead we sampled only 3 distances from reef in order to increase the replication within habitats and sites and thereby increase the power of the study.
The 4 sites used for on-reef and near-reef treatments were North Carnac, South Carnac, SW Carnac and Herring Bay. In choosing these on- and near-reef sites, consideration was given to the presence of high-relief reef ( $>0.5 \mathrm{~m}$ above the ocean floor), the presence of patches of a Posidonia sinuosa meadow within $20 \mathrm{~m}$ of reef, and shallow water depth $(<5 \mathrm{~m})$. We chose 4 sites within Parmelia Bank for the distant-from-reef treatment. These sites were all relatively shallow (approx. $4 \mathrm{~m}$ deep) and contained patches of $P$. sinuosa of similar density and size (Kendrick et al. 2000); they were a minimum of $100 \mathrm{~m}$ apart, and were at least $3 \mathrm{~km}$ from the nearest known reef

Test 1: Propagule availability. To determine if propagule availability differed among sites with different proximity to reefs, water samples containing algal propagules were collected from all sites over $2 \mathrm{~d}$ in November. A boat-mounted bilge pump attached to a plastic hose was steadily moved vertically through the water column (at about $10 \mathrm{~m} \mathrm{~min}^{-1}$ ) to provide a 101 vertically integrated water sample from each site. The sample was filtered through a $3 \mu \mathrm{m}$ phytoplankton net and the concentrate transferred to high-density polyethylene containers, each with a $6 \mathrm{~cm}$ diameter polyethylene disc fixed to the bottom of the container. Samples were stored upright in a cool dark box, transported to the laboratory, and incubated under 2 fluorescent Grolux lights (F30W/GRO-T8) on a $12 \mathrm{~h}$ day/night regime at $20^{\circ} \mathrm{C}$ (Bellgrove et al. 1997). Samples were left for $48 \mathrm{~h}$ to allow propagules to settle onto the polyethylene discs before transferring the discs into fresh, sterile jars containing $100 \mathrm{ml}$ autoclaved seawater $\left(110^{\circ} \mathrm{C}\right.$ for $\left.10 \mathrm{~min}\right)$ enriched with $2 \mathrm{ml}$ Provasoli ES medium (Bold \& Wynne 1978). Lids were loosely closed to allow airflow, and the media was changed twice weekly. After $24 \mathrm{~d}, 5 \mathrm{ml}$ of formalin was added to each culture jar to preserve algal recruits. After a further $24 \mathrm{~h}$ the media was replaced with fresh autoclaved seawater to minimise loss of colour and damage to cell tissue. Identification of recruits was only possible to genus level for many individuals.

Test 2: Epiphyte recruitment. Artificial seagrass was chosen over natural seagrass to study epiphyte recruitment, as it was not possible to standardise the age of leaves to make accurate comparisons among habitats. Pinckney \& Micheli (1998) suggested that Zostera marina and Halodule wrightii leaves regulate the composition of microalgae growing on them through competitive interactions. However, there is no such evidence for macroalgal epiphytes on species of Posidonia. On the contrary, a number of studies present correlative data that suggest it is not the nature of the substratum but the period of availability of the substratum that determines epiphyte communities (Kendrick \& Hawkes 1988, Borowitzka et al. 1990, Kendrick \& 
Burt 1997). Horner (1987) showed that epiphytic algal biomass distribution on artificial seagrass was similar to that of natural Posidonia leaves, and other authors have successfully used artificial substratum to quantify the effects of nutrient enrichment on epiphyte productivity (Hillman et al. 1994).

Artificial seagrass units (ASU) closely resembling Posidonia sinuosa were constructed using the method of Horner (1987). Artificial seagrass shoots consisted of 2 strips of clear flexible polyethylene, 200 or $400 \mathrm{~mm}$ long and $10 \mathrm{~mm}$ wide $\times 300 \mu \mathrm{m}$ thick, to mimic the younger and older leaves of a typical shoot. Each shoot was threaded through and stapled to plastic coated wire grids $150 \times 150 \mathrm{~mm}$ in outside dimensions with $25 \times 25 \mathrm{~mm}$ apertures. We attached 16 shoots to each grid; 4 ASU were randomly placed within seagrass patches at each site (from which underlying plant material had been removed) and anchored to the substratum by $30 \mathrm{~cm}$ steel tent pegs and weights. The ASU were deployed in October and November and after 8 to $10 \mathrm{wk}$, the grids were retrieved, carefully placed in separate plastic bags containing seawater and stored on ice for transport to the laboratory, where they were processed within $24 \mathrm{~h}$.

In the laboratory, 3 plastic shoots were randomly selected from each ASU grid and the composition and abundance of epiphytic species recorded. These shoots were then preserved in 5\% seawater-formaldehyde solution. A pilot study had previously shown that 3 shoots were sufficient for representation of taxon richness of a sample.

Biomass of algal epiphytes was determined for the ASU. We randomly selected 5 plastic shoots of each sample and determined dry weight (DW) of epiphytic macroalgae for all 5 plastic shoots combined. Approximately $1 \mathrm{~cm}$ was cut off the bottom of each shoot to remove staples. Epiphytic fauna were removed from the leaves. The leaves were then gently washed in seawater over a sieve to remove sediment; any dislodged epiphytic material was captured in the sieve. The remaining epiphytes were then scraped from shoots using a single-sided razor-blade, placed in preweighed crucibles that had been pre-fired to $950^{\circ} \mathrm{C}$, oven-dried at $80^{\circ} \mathrm{C}$ for $48 \mathrm{~h}$, and reweighed to determine dry weight (DW). Data were normalised to g DW shoot $^{-1}$.

Test 3: Developed assemblages. Samples of naturally occurring Posidonia sinuosa were collected from each distant-from-reef and near-reef site where ASU were deployed. On-reef samples were not collected, as $P$. sinuosa does not grow on the reef itself. All aboveground vegetative material was collected from 4 randomly located $10 \times 10 \mathrm{~cm}$ quadrats at each site and placed in plastic bags while under water. Samples were kept on ice and transported to the laboratory, where they were preserved in 5\% formaldehyde in seawater and stored in the dark until processed. We randomly selected 1 shoot from each quadrat, and recorded the epiphyte species and abundance for the oldest leaf, as detailed below.

Epiphyte identification/abundance. Epiphytes were identified using the taxonomic keys of Womersley (1984, 1987, 1994, 1996), and Huisman \& Walker (1990). The species occurring on each shoot were recorded and the percentage cover of each species estimated. Cover values were recorded on a scale from 1 to 6 corresponding with percentage-cover categories of $0-1$, $2-9,10-29,30-54,55-79$ and $80-100 \%$ (Kendrick \& Lavery 2001). Vouchers of each taxon were made by preserving, staining and mounting material on microscope slides following the method of Womersley (1984), and are held at Edith Cowan University, sJoondalup, Western Australia.

Statistical analysis. Univariate analysis: Nested analysis of variance was used to test for differences in taxonomic richness (hereafter referred to as 'taxon richness') among habitats and among sites nested within habitats. We report taxon richness rather than species richness as the encrusting coralline algae could not be separated to species level and are referred to as coralline species (spp.). Levene's test indicated that the variances were often heterogeneous, even after square-root transformations. As ANOVA is considered to be robust to heterogeneity of variance (Chapman et al. 1995) when equal sample sizes are involved (Kendrick 1991), it was considered appropriate to continue with parametric analyses of data. To compensate for the possibility of an erroneous conclusion, the significance level was set at 0.01 when data failed to conform to homogeneity of variance. If data conformed to homogeneity of variance, the significance level was set at 0.05 . When ANOVA indicated a significant difference among habitats, multiple, pairwise post-hoc comparisons of means were performed (Games-Howell test; Sokal \& Rohlf 1981).

Multivariate analysis: Multivariate analysis was conducted using the PRIMER software analysis package (Carr 1997) to explore for patterns in algal epiphyte assemblages in relation to proximity to reef. The full set of taxa abundance data (i.e. untransformed median-cover category values) was used (total: $\mathrm{n}=48$ for artificial seagrass $; \mathrm{n}=36$ for propagule culture $\mathrm{n}=32$ for natural seagrass). We performed 2-dimensional non-metric multidimensional scaling (NMDS) ordinations to reveal patterns of similarity among epiphyte assemblages at different sites, based on a Bray-Curtis similarity matrix. The Bray-Curtis measure was selected as it is the most commonly used association measure in ecological studies and is robust to the non-linear species responses typical of ecological data (Faith et al. 1987). 
To examine the significance of patterns in species composition among habitats and among sites within habitats, we conducted analysis of similarities (ANOSIM) based on Bray \& Curtis similarity values calculated from untransformed proportion data, using PRIMER. We conducted a 2-way nested ANOSIM (Clarke 1993) to test for differences among habitats and among sites within habitats, followed by pairwise comparisons. The R statistic from all analyses is synonymous with both Clarke's R and global R. The number of permutations used in each test was either 5000, or where this could not be achieved (due to limited sample size) the maximum possible number of permutations.

To determine the epiphytic macroalgae taxa that contributed most strongly to dissimilarities among samples from different habitats, we used the SIMPER method described by Clarke (1993). This procedure examines the contribution of individual species to the similarity matrix by computing the average dissimilarity among all pairs of group samples, and then breaks the average down into the separate contributions from each species to the average dissimilarity (Clarke \& Warwick 1994).

\section{RESULTS}

\section{Propagule assemblages}

Laboratory culture of propagules collected from each site produced 14 algal taxa: 1 Cyanophyta, 3 Rhodophyta, 4 Chlorophyta and 6 Phaeophyta (Table 1). Of these 14 taxa, 11 were collected from water samples taken on- and near-reef sites, while only 7 were collected from distantfrom-reef sites. Sphacelaria spp., Enteromorpha flexuosa, E. paradoxa, Hincksia mitchelliae and Ulva spp. were common to all 3 habitats. Ceramium macilentum only occurred in near-reef samples, while encrusting coralline species were detected only in 1 on-reef sample.
Table 1. Macroalgae taxa collected as propagules in water column, or as thalli on artificial seagrass and Posidonia sinuosa at sites of varying proximity to reefs. on: on-reef; near: $<20 \mathrm{~m}$ from reef; dist.: $>3 \mathrm{~km}$ from reef; $\mathrm{X}$ : presence

\begin{tabular}{|c|c|c|c|c|c|c|c|c|}
\hline \multirow[b]{2}{*}{ Rhodophyta } & \multicolumn{3}{|c|}{$\begin{array}{l}\text { Propagules } \\
\text { On Near Dist. }\end{array}$} & \multicolumn{3}{|c|}{$\begin{array}{l}\text { Artif. seagrass } \\
\text { On Near Dist. }\end{array}$} & \multicolumn{2}{|c|}{$\begin{array}{l}\text { P. sinuosa } \\
\text { Near Dist. }\end{array}$} \\
\hline & & & & & & & & \\
\hline Acrosorium sp. 1 & & & & & & & $\mathrm{X}$ & \\
\hline Aglaothamnion sp. 1 & & & & & & $\mathrm{X}$ & $\mathrm{X}$ & $\mathrm{X}$ \\
\hline Amphiplexia hymenocladiodes & & & & $\mathrm{X}$ & $\mathrm{X}$ & & $\mathrm{X}$ & \\
\hline Anotrichium liemophora & & & & & $\mathrm{X}$ & $\mathrm{X}$ & $\mathrm{X}$ & $\mathrm{X}$ \\
\hline Anotrichium tenue & & & & $\mathrm{X}$ & $\mathrm{X}$ & & $\mathrm{X}$ & \\
\hline Antithamnion hanowiodes & & & & & $\mathrm{X}$ & $\mathrm{X}$ & & $\mathrm{X}$ \\
\hline Asparagopsis sp. 1 & & & & $\mathrm{X}$ & $\mathrm{X}$ & & & \\
\hline Bornetia binderiana & & & & $\mathrm{X}$ & & $\mathrm{X}$ & $\mathrm{X}$ & $\mathrm{X}$ \\
\hline Brongniartella sp. 1 & & & & & $\mathrm{X}$ & & & \\
\hline Callithamnion sp. 1 & & & & $\mathrm{X}$ & $\mathrm{X}$ & $\mathrm{X}$ & & $\mathrm{X}$ \\
\hline Centroceras clavulatum & & & & $\mathrm{X}$ & $\mathrm{X}$ & & $\mathrm{X}$ & $\mathrm{X}$ \\
\hline Ceramium isogonum & & & & $\mathrm{X}$ & $\mathrm{X}$ & $\mathrm{X}$ & $\mathrm{X}$ & \\
\hline Ceramium macilentum & & $\mathrm{X}$ & & $\mathrm{X}$ & $\mathrm{X}$ & $\mathrm{X}$ & $\mathrm{X}$ & $\mathrm{X}$ \\
\hline Ceramium puberulum & & & & $\mathrm{X}$ & $\mathrm{X}$ & $\mathrm{X}$ & $\mathrm{X}$ & $\mathrm{X}$ \\
\hline Ceramium rubrum & & & & $\mathrm{X}$ & $\mathrm{X}$ & $\mathrm{X}$ & & $\mathrm{X}$ \\
\hline Champia viridis & & & & $\mathrm{X}$ & $\mathrm{X}$ & $\mathrm{X}$ & $\mathrm{X}$ & \\
\hline Champia zostericola & & & & $\mathrm{X}$ & $\mathrm{X}$ & & & \\
\hline Chondria juvenile spp. & & & & & & & $\mathrm{X}$ & \\
\hline Chondria sp. 1 & & & & & & & $\mathrm{X}$ & \\
\hline Chondria sp. 2 & & & & & & & & $\mathrm{X}$ \\
\hline Chondria curdeiana & & & & $\mathrm{X}$ & $\mathrm{X}$ & & $\mathrm{X}$ & $\mathrm{X}$ \\
\hline Coralline encrusting & $\mathrm{X}$ & & & $\mathrm{X}$ & $\mathrm{X}$ & $\mathrm{X}$ & $\mathrm{X}$ & $\mathrm{X}$ \\
\hline Craspedocarpus venosus & & & & & & $\mathrm{X}$ & & \\
\hline Dasya sp. 1 & & & & & & $\mathrm{X}$ & & $\mathrm{X}$ \\
\hline Dasyaceae spp. & & & $\mathrm{X}$ & & & & & \\
\hline Dasyclonium sp. 1 & & & & & $\mathrm{X}$ & & & \\
\hline Dipterosiphonia sp. 1 & & & & & $\mathrm{X}$ & $\mathrm{X}$ & & $\mathrm{X}$ \\
\hline Dipterosiphonia sp. 2 & & & & & $\mathrm{X}$ & $\mathrm{X}$ & & \\
\hline Griffithsia ovalis & & & & $\mathrm{X}$ & $\mathrm{X}$ & & $\mathrm{X}$ & $\mathrm{X}$ \\
\hline Haliptilon roseum & & & & $\mathrm{X}$ & $\mathrm{X}$ & $\mathrm{X}$ & & $\mathrm{X}$ \\
\hline Herposiphonia tenella & & & & & $\mathrm{X}$ & $\mathrm{X}$ & $\mathrm{X}$ & $\mathrm{X}$ \\
\hline Heterosiphonia sp. 1 & & & & & & & & $\mathrm{X}$ \\
\hline Heterosiphonia calothamnii & & & & & & & & $\mathrm{X}$ \\
\hline Hypnea sp. 1 & & & & $\mathrm{X}$ & $\mathrm{X}$ & $\mathrm{X}$ & $\mathrm{X}$ & \\
\hline Jania minuta & & & & & & $\mathrm{X}$ & & $\mathrm{X}$ \\
\hline Laurencia filiformis & & & & & $\mathrm{X}$ & $\mathrm{X}$ & & $\mathrm{X}$ \\
\hline Laurencia juvenile spp. & & & & & $\mathrm{X}$ & $\mathrm{X}$ & $\mathrm{X}$ & $\mathrm{X}$ \\
\hline Laurencia majuscela & & & & $\mathrm{X}$ & $\mathrm{X}$ & & & $\mathrm{X}$ \\
\hline Laurencia sp. 3 & & & & $\mathrm{X}$ & & & & \\
\hline Metagoniolithon steliferum & & & & $\mathrm{X}$ & $\mathrm{X}$ & & & \\
\hline Platysiphonia miniata & & & & & & $\mathrm{X}$ & & \\
\hline Polysiphonia amphibolis & & & & & & $\mathrm{X}$ & & $\mathrm{X}$ \\
\hline Polysiphonia forfex & & & & $\mathrm{X}$ & $\mathrm{X}$ & & $\mathrm{X}$ & \\
\hline Polysiphonia infestans & & & & $\mathrm{X}$ & $\mathrm{X}$ & & & \\
\hline Polysiphonia mollis & & & & $\mathrm{X}$ & $\mathrm{X}$ & $\mathrm{X}$ & $\mathrm{X}$ & $\mathrm{X}$ \\
\hline Red corticated sp. 1 & & & & & & & $\mathrm{X}$ & \\
\hline Semnocarpa minuta & & & & $\mathrm{X}$ & $\mathrm{X}$ & & $\mathrm{X}$ & \\
\hline Spyridia filamentosa & & & & & $\mathrm{X}$ & & & $\mathrm{X}$ \\
\hline Stigonema sp. 1 & & & & $\mathrm{X}$ & $\mathrm{X}$ & $\mathrm{X}$ & & \\
\hline Wrangelia plumosa & & & & $\mathrm{X}$ & $\mathrm{X}$ & & & \\
\hline
\end{tabular}

Table (continued on next page) 
Table 1 (continued)

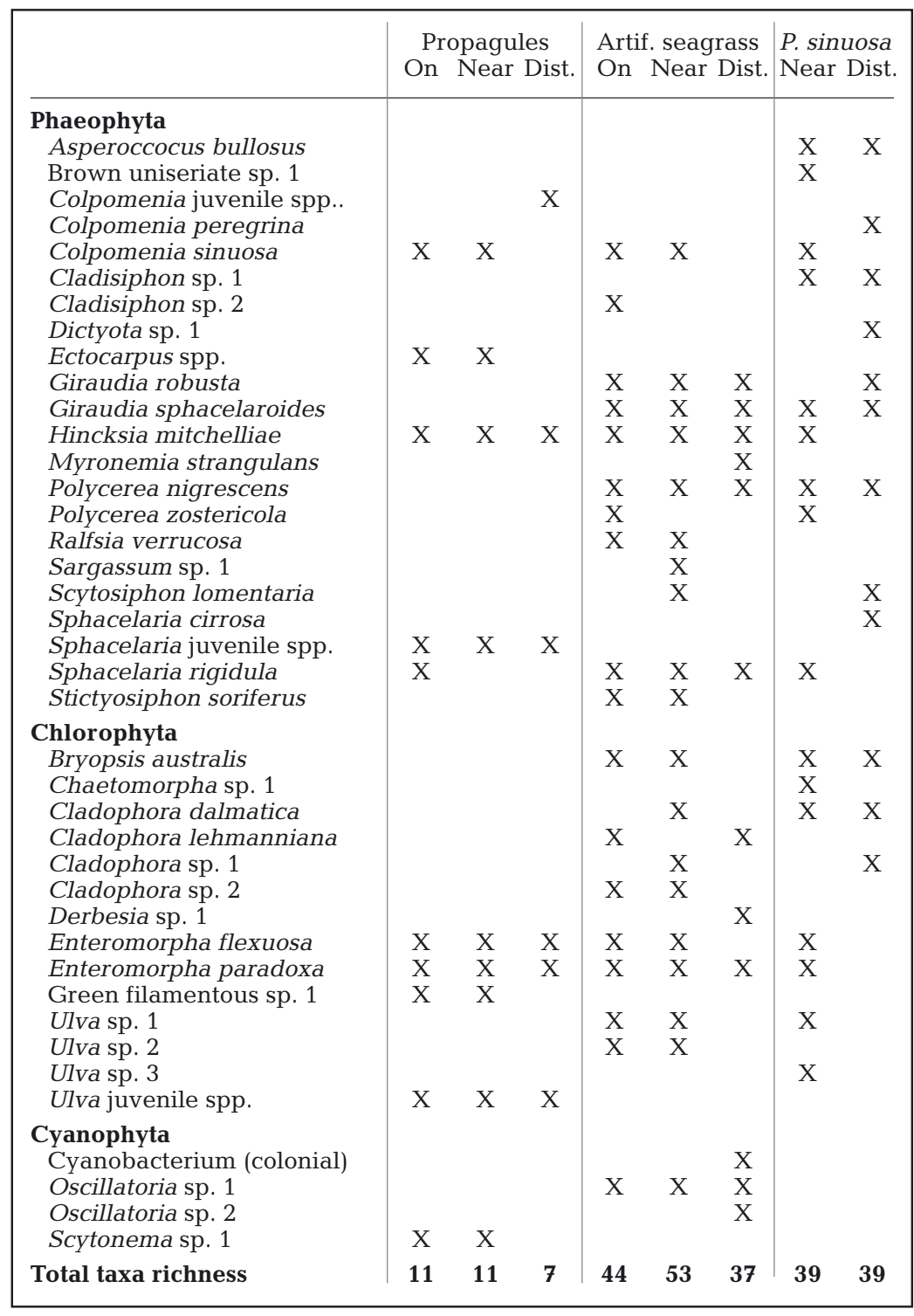

Table 2. Results of 2-factor nested ANOVA testing for differences in taxon richness of propagules, epiphytes grown on artificial seagrass and epiphytes recorded on natural Posidonia sinuosa leaves between habitats of varying proximity to reefs and sites nested within those habitats. Significant p-values are in boldface

\begin{tabular}{|lcccc|}
\hline Factor = species richness & df & MS & $F$ & $p$ \\
\hline Propagules & & & & \\
$\quad$ Habitat & 2 & 9.33 & 5.04 & $\mathbf{0 . 0 3 4}$ \\
$\quad$ Sites (Habitat) & 9 & 1.85 & 1.09 & 0.404 \\
Artificial seagrass & & & & \\
$\quad$ Habitat & 2 & 2.11 & 1.44 & 0.288 \\
$\quad$ Sites (Habitat) & 9 & 1.47 & 4.18 & $<\mathbf{0 . 0 0 1}$ \\
P. sinuosa & & & & \\
$\quad$ Habitat & 1 & 0.09 & 0.03 & 0.86 \\
$\quad$ Sites (Habitat) & 6 & 2.64 & 10.62 & $<\mathbf{0 . 0 0 1}$ \\
\hline
\end{tabular}

Taxon richness was lowest for distant-from-reef sites, while on-reef and near-reef sites had higher and more variable taxonomic richness. Analysis of variance on untransformed data (homogeneous as confirmed by Levene's test $p=0.06$ ) indicated significant differences among habitats and no significant differences among sites within habitats (Table 2). GamesHowell post-hoc testing showed that taxon richness of propagules collected from distant-from-reef sites was lower than those collected from on- and near-reef sites (Fig. 2).

The NMDS ordination of taxon abundance revealed a clustering of samples according to habitat, though this was not a strong separation (Fig. 3). ANOSIM confirmed the significance of the clustering pattern, with a significant difference among habitats $(\mathrm{p}=0.02)$ and sites-within-habitat $(\mathrm{p}=$ 0.001; Table 3). Pairwise comparisons revealed that for each combination of habitats only on-reef and away-fromreef sites were significantly different from each other $(p=0.03)$. This was partly driven by the low number of taxa collected during the propagule sampling. Hincksia mitchelliae and Ulva spp. were responsible for $90 \%$ of the differences between away-fromreef sites and the other habitats. The same taxa were present in on-reef and near-reef samples, although their relative contribution to assemblage structure was smaller (Table 4).

\section{Epiphyte recruitment}

\section{Taxon richness}

We identified 68 epiphytic algae taxa growing on shoots of artificial seagrass across all habitats during the study period: 3 Cyanophyta, 13 Phaeophyta, 10 Chlorophyta and 42 Rhodophyta (Table 1). The nearreef habitat supported the highest total number of taxa (53), followed by on-reef (44) and distant-from-reef (37) sites. Of the species recorded, 30\% were common to all 3 habitats, while on- and near-reef habitats shared more species with each other than with distantfrom-reef habitat; $17 \%$ of distant-from-reef species were unique to that habitat, compared to $12 \%$ for near- 

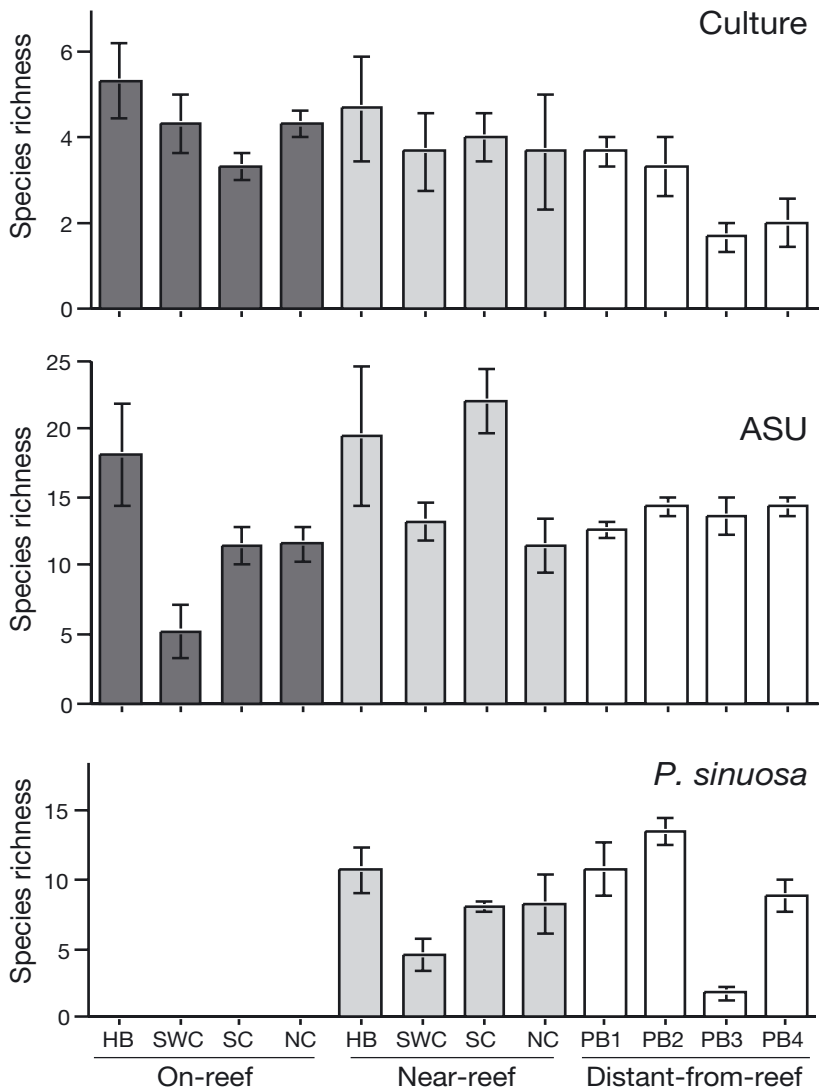

Fig. 2. Mean taxon richness of macroalgae recorded from laboratory culture of algal propagules, artificial seagrass units and Posidonia sinuosa leaves at sites on-reef (dark bars), near-reef (grey) and distant-from-reef (white) sites. Data are means \pm SE. $\mathrm{n}=3$ (cultures) or $\mathrm{n}=4$ (ASU and $P$. sinuosa samples). PB: Parmelia Bank; other abbreviations as in Fig. 1 reef and $5 \%$ for on-reef habitats; 14 species occurred at only 1 of the 12 sites studied.

Taxon richness was highly variable within sites. This localised patchiness dominated any variation in species richness among habitats. Species richness was significantly different among sites nested within habitats $(p<0.001$; Table 2). Mean species richness for each site was relatively consistent for distant-from-reef sites $(13.25 \pm 0.85 \mathrm{SE}$ to $15.25 \pm 0.64 \mathrm{SE})$ but considerably more variable for the other 2 habitat types (on-reef = $5.50 \pm 1.89 \mathrm{SE}$ to $18.25 \pm 3.32$; near-reef $=11.25 \pm 1.71$ $\mathrm{SE}$ to $22.25 \pm 2.14 \mathrm{SE}$ ) (Fig. 2).

\section{Assemblage structure}

Epiphyte assemblages on artificial seagrass differed among the habitats, with the most apparent trend being the clear separation of samples from the distant-to-reef habitat from the other habitats (Fig. 3). A 2-way nested ANOSIM confirmed the significance of differences among habitats ( $p=0.002$; Table 3 ) and sites within habitats $(p<0.0001)$. Therefore, the null hypotheses of no significant differences in epiphytic assemblages recruited to artificial seagrass among sites within habitat and among habitats were rejected. Pairwise comparisons showed that on- and near-reef assemblages of epiphytes on ASU were not significantly different $(p=0.43)$ while distant-from-reef assemblages were significantly different for these habitats $(p=0.03)$. Near-reef assemblages were dominated by 2 filamentous brown species, Polycerea nigrescens and Hincksia mitchelliae. Distantfrom-reef assemblages were also dominated by fila-

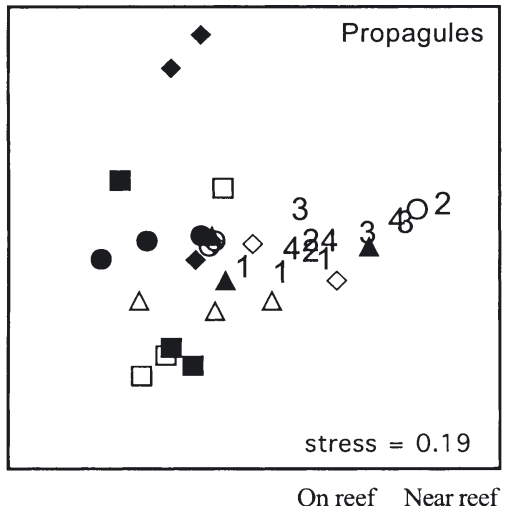

Herring Bay

South Carnac Is.

South-west Carnac Is.

North Carnac Is.

Parmelia Bank
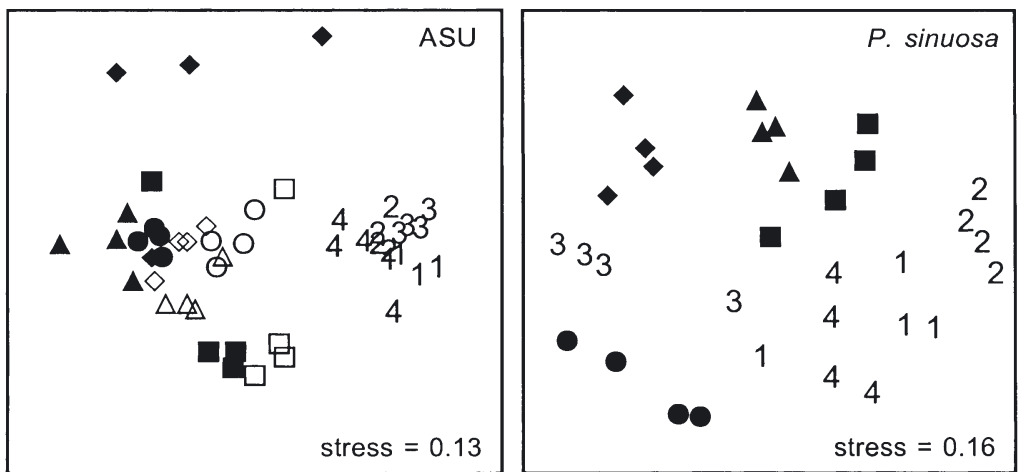

Distant

$\begin{array}{ll}\square & \mathbf{a} \\ \Delta & \mathbf{\Delta} \\ \diamond & \vec{\bullet} \\ 0 & \bullet\end{array}$

Fig. 3. Results of 2-dimensional NMDS ordination of epiphytic macroalgae assemblages at on-reef, near-reef $(<20 \mathrm{~m}$ distant $)$ and distant-from-reef (>3 km distant) sites as propagules in the water column, thalli on artificial seagrass units (ASU) and thalli on Posidonia sinuosa leaves. Ordinations were based on Bray-Curtis dissimilarity matrices calculated from untransformed median abundance values. $(\square)(\square)$ on- and near-reef Herring Bay, respectively; $(\diamond)(\diamond)$ on- and near-reef South-west Carnac Island; $(\Delta)(\boldsymbol{\Delta})$ on- and near-reef South Carnac Island; $(O)(\bullet)$ on- and near-reef North Carnac Island; 1-4: seagrass sites distant from reef 
Table 3. Results of ANOSIM testing for differences in composition of epiphytic macroalgae assemblages occurring as propagules or as thalli on artificial seagrass (ASU) and Posidonia sinuosa between different sites, between habitats of differing proximity to reefs (Habitats) and pairwise comparisons of habitats. R: R statistic (also referred to as Clarke's R or global R). Significant p-values are in boldface

\begin{tabular}{|llrrr|}
\hline Experiment & Groups tested & $\mathrm{R}$ & Permutations & $\mathrm{p}$ \\
\hline Propagules & Between sites & 0.30 & 1000 & $\mathbf{0 . 0 0 1}$ \\
& Between habitats & 0.33 & 5775 & $\mathbf{0 . 0 2 4}$ \\
& on vs near & -0.01 & 35 & 0.514 \\
& on vs distant & 0.62 & 35 & $\mathbf{0 . 0 2 9}$ \\
& near vs distant & 0.33 & 35 & 0.114 \\
ASU & & & & \\
& Between sites & 0.60 & 1000 & $<\mathbf{0 . 0 0 1}$ \\
& Between habitats & 0.64 & 5775 & $\mathbf{0 . 0 0 2}$ \\
& on vs near & 0.00 & 35 & 0.429 \\
& on vs distant & 0.93 & 35 & $\mathbf{0 . 0 2 9}$ \\
& near vs distant & 0.92 & 35 & $\mathbf{0 . 0 2 9}$ \\
& & & & \\
& Between sites & 0.93 & 1000 & $<\mathbf{0 . 0 0 1}$ \\
& Between habitats & 0.35 & 35 & 0.057 \\
\hline
\end{tabular}

mentous brown algae, but the species were different and included Giraudia robusta, Polycerea zostericola and Sphacelaria rigidula. Articulated coralline algae were conspicuous components of distant-from-reef assemblages but were absent from near-reef assemblages.

The number of different epiphyte taxa contributing to the similarity of assemblages on ASU within habitats increased with increasing distance from reef (Table 4). This pattern was similar to that shown in the propagule availability experiment. With regard to assemblage structure, 9 taxa accounted for $90 \%$ of the structure of on-reef sites and 14 species for the structure on near-reef sites. Of these, 5 were common to both habitats (encrusting coralline species, Polycera nigrescens, Hincksia mitchelliae, Ceramium isogonum and Polysiphonia mollis). In contrast, 10 taxa contributed to the same percentage for near-reef sites, with only 2 (encrusting corallines and Sphacelaria rigidula) found at both nearreef and on-reef sites. Thus, on-reef and near-reef assemblages had a relatively high proportion of common species, reducing the differences among these assemblages, while distant-from-reef sites had fewer species in common with either of the other 2 habitats.

Table 4. Results of SIMPER showing percentage of species contribution to community structure of propagules in the water column, thalli on artificial seagrass units (ASU) and thalli on Posidonia sinuosa (based on untransformed median category values). Data are for species that cumulatively account for first $90 \%$ of similarity within groups

\begin{tabular}{|c|c|c|c|c|c|c|}
\hline & \multicolumn{2}{|l|}{ On reef } & \multicolumn{2}{|l|}{ Near reef } & \multicolumn{2}{|l|}{ Distant from reef } \\
\hline & Species & $\%$ & Species & $\%$ & Species & $\%$ \\
\hline \multirow[t]{4}{*}{ Propagules } & Ulva juvenile sp. & 44.2 & Hincksia mitchelliae & 52.9 & Hincksia mitchelliae & 63.9 \\
\hline & Enteromorpha paradoxa & 17.8 & Ulva juvenile sp. & 21.1 & Ulva juvenile sp. & 27.4 \\
\hline & Hincksia mitchelliae & 17.1 & Enteromorpha flexuosa & 10.6 & & \\
\hline & Enteromorpha flexuosa & 16.1 & Sphacelaria sp. & 9.9 & & \\
\hline \multirow[t]{14}{*}{ ASU } & Coralline encrusting & 24.0 & Polycerea nigrescens & 25.2 & Coralline encrusting & 26.5 \\
\hline & Polycerea nigrescens & 21.1 & Coralline encrusting & 25.1 & Giraudia robusta & 11.4 \\
\hline & Hincksia mitchelliae & 18.0 & Hincksia mitchelliae & 11.1 & Polycerea zostericola & 11.3 \\
\hline & Ceramium isogonum & 8.3 & Colpomenia sinuosa & 6.2 & Sphacelaria rigidula & 9.9 \\
\hline & Colpomenia sinuosa & 7.1 & Ceramium isogonum & 6.0 & Haliptilon roseum & 8.1 \\
\hline & Polysiphonia mollis & 6.4 & Polysiphonia mollis & 4.9 & Myronemia strangulans & 6.4 \\
\hline & Polysiphonia forfex & 2.5 & Sphacelaria rigidula & 4.2 & Oscillatoria sp. 1 & 5.4 \\
\hline & Enteromorpha paradoxa & 2.4 & Wrangelia plumosa & 1.4 & Ceramium puberulum & 4.5 \\
\hline & Sphacelaria rigidula & 1.8 & Ceramium macilentum & 1.4 & Laurencia juvenile sp. & 4.4 \\
\hline & & & Centroceras clavulatum & 1.3 & Jania minuta & 3.9 \\
\hline & & & & & Laurencia juvenile spp. & 1.1 \\
\hline & & & & & Enteromorpha paradoxa & 1.0 \\
\hline & & & & & Champia zostericola & 1.0 \\
\hline & & & & & Stictyosiphon soriferus & 0.9 \\
\hline \multirow[t]{8}{*}{ P. sinuosa } & & & Coralline encrusting & 68.4 & Coralline encrusting & 64.5 \\
\hline & & & Ceramium macilentum & 5.8 & Sphacelaria rigidula & 7.1 \\
\hline & & & Hincksia mitchelliae & 5.8 & Anotrichium liemophora & 6.4 \\
\hline & & & Centroceras clavulatum & 3.6 & Ceramium rubrum & 3.8 \\
\hline & & & Sphacelaria rigidula & 2.8 & Ceramium puberulum & 3.0 \\
\hline & & & Ceramium puberulum & 2.4 & Dasya sp. 1 & 2.8 \\
\hline & & & Colpomenia sinuosa & 2.2 & Laurencia filiformis & 2.3 \\
\hline & & & & & Sphacelaria cirrosa & 1.6 \\
\hline
\end{tabular}


Table 5. Results of 2-factor nested ANOVA testing for differences in biomass between habitats (on-reef, near-reef, distantfrom-reef) and between 4 sites nested within habitats. All data square-root $(x+1)$-transformed

\begin{tabular}{|lrrcrr|}
\hline Variable & df & SS & MS & \multicolumn{1}{c|}{$F$} & \multicolumn{1}{c|}{ p } \\
\hline Habitat & 2 & 4.997 & 2.498 & 36.398 & $<0.001$ \\
Site (Habitat) & 9 & 2.198 & 0.244 & 3.557 & 0.003 \\
Residual & 36 & 2.471 & & & \\
\hline
\end{tabular}

Biomass

Biomass was only recorded for ASU epiphyte assemblages. The mean dry weight of epiphytes on ASU differed significantly among habitats and among sites within each habitat (Table 5). Mean biomass was greatest on the ASU in the near-reef habitat $(0.63 \pm$ $0.11 \mathrm{~g} \mathrm{shoot}^{-1}$ ) followed by the on-reef habitat and the distant-from-reef habitat $(0.18 \pm 0.04$ and $0.11 \pm 0.01 \mathrm{~g}$ shoots $^{-1}$, respectively; Fig. 4). Post-hoc pairwise comparisons confirmed that the mean biomass at the nearreef habitat was significantly higher than at either of the other habitats (Games-Howell test; $\mathrm{p}<0.05$ ), which were not significantly different from each other. Variability in mean biomass also differed among habitats. Mean biomass values were more consistent for sites nested within the distant-from-reef habitat and more variable for sites nested within near- and on-reef habitats.

\section{Epiphyte assemblages on Posidonia sinuosa}

\section{Taxon richness}

We identified 59 taxa of algal epiphytes growing on Posidonia sinuosa at near-reef and distant-from-reef sites, 37 Rhodophyta, 14 Phaeophyta and 8 Chlorophyta (Table 1). Of these, 40 were recorded in only 1 habitat, with only 19 taxa common to both.

Species richness of epiphytes occurring on Posidonia sinuosa was highly variable among sites within habitat. Mean and standard error of taxon richness varied from $5.5 \pm 1.1$ to $10.2 \pm 1.9$ for near-reef and $2.2 \pm 0.5$ to $14.2 \pm 0.7$ for away-fromreef sites (Fig. 2). There were no significant differences between near-reef and awayfrom-reef habitats $(p=0.86)$, with differences among sites within habitats being significant $(\mathrm{p}<0.001)$ (Table 2$)$.
Assemblage structure

Epiphytic algae assemblages growing on Posidonia sinuosa in meadows distant from reef clustered to the right of the ordination and away from assemblages found in near-reef meadows, with the exception of Parmelia Bank Site 3, which clustered among the nearreef sites (Fig. 3). ANOSIM indicated a significance value of $p=0.057$ for difference between near-to-reef and distant-from-reef assemblages, that is, the differences were not significant (Table 3). However, it is worth noting that this test had only 35 permutations, due to the low number of samples. Because of this, the degree of significance indicates that only 2 out of 57 random permutations of the samples produced greater $\mathrm{R}$-values than the observed $\mathrm{R}$, and with this low number of permutations significance changes in steps of $p=$ 0.028. In other words, if 1 permutation less had been significantly different, the statistical significance would have been $\mathrm{p}=0.028$. Thus, the low sample size introduces the prospect of mathematical artefacts in the test, and we interpret the outcome as more suggestive of significance than non-significance. Differences among sites within habitat were significant at $\mathrm{p}<0.001$.

Coralline encrusting algae accounted for most of the contribution to similarity within both habitats (Table 4); of the remaining species contributing to similarity, the filamentous brown alga Sphacelaria rigidula and the red alga Ceramium puberulum were found in both habitats. Of the other species, filamentous and fleshy red algae contributed to the similarity within the distant-from-reef habitat, while the brown algae Hincksia mitchelliae and Colpomenia sinuosa contributed to the similarity among near-reef sites.

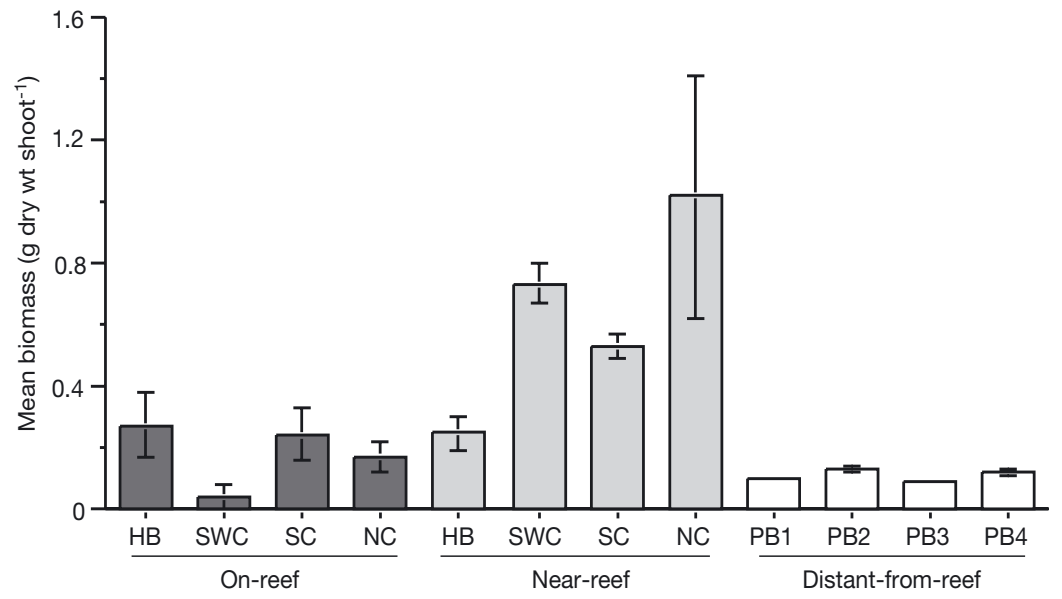

Fig. 4. Mean $( \pm \mathrm{SE}, \mathrm{n}=4$ ) biomass (dry weight) of epiphytic macroalgae recorded on shoots of artificial seagrass (ASU) at sites in different habitats. PB: Parmelia Bank; other abbreviations as in Fig. 1. Grand means for each habitat are given in 'Results' 


\section{DISCUSSION}

Our findings showed that biomass and species composition of epiphytic macroalgae assemblages on seagrasses differed among habitats of varying proximity to reefs. Biomass on artificial seagrass was substantially higher and more variable within near-reef sites. Culture of propagules available in the water column, on a single sampling date, indicated that there were differences in taxon richness and composition of propagules among the habitats. These differences were most evident between on-reef and distant-fromreef habitats, consistent with the observation of Borowitzka \& Lethbridge (1989) that the assemblage of propagules available for recruitment to seagrasses varied with proximity to reefs. The strongest evidence of an influence of habitat on epiphyte diversity was found in the assemblages recruiting to artificial seagrass: assemblages recruiting to on- and near-reef sites were similar, but assemblages recruiting to distant-fromreef were different, with a majority of taxa unique to these samples. Epiphyte assemblages on Posidonia sinuosa at near-to- and distant-from-reef habitats were also distinct, although greater variation among sites within each of these habitats resulted in the differences being less significant. This site variation in mature epiphytic assemblages may indicate an influence of post-recruitment processes in determining the eventual algal epiphyte assemblages on P. sinuosa, and may lessen differences that exist at recruitment.

Comparison of propagule culture and artificial seagrass ordinations showed that the differences between near-reef and distant-from-reef assemblages were more pronounced in 'younger' artificial blades; $\mathrm{R}$ increased from 0.33 to 0.92 for propagule and ASU assemblages, respectively. This may indicate a genuine intensification of differences between assemblages from pre-recruitment to recruitment phases due to the action of post-recruitment processes such as grazing and hydrodynamics. However, it is more likely that the observation is simply an artefact of the sampling timescales in the 2 parts of the study. The propagule availability experiment involved measuring a single, stochastic seeding event, while the ASU were exposed to a continual rain of propagules over an 8 to 10 wk period.

If the relationship between proximity to reef and epiphytic algal composition is a simple one, then we would expect the dissimilarity among assemblages to increase as their distance from the same reef increased. This pattern was observed for assemblages on $\mathrm{ASU}$; near-reef assemblages were essentially the same as on-reef assemblages ( $R=0.00$; Table 3$)$ but distant-from-reef assemblages were highly dissimilar from those on-reef $(R=0.93)$ and only slightly less dis- similar from near-reef $(R=0.92)$ assemblages. However, the differences between near-reef and distantfrom-reef assemblages were less pronounced on the oldest leaves of Posidonia sinuosa than on ASU; whereas ASU assemblages distant from reefs were highly dissimilar to those near reefs $(\mathrm{R}=0.92)$, for assemblages on $P$. sinuosa the corresponding $\mathrm{R}$ value was 0.35 .

There are 3 likely contributors to this observed weaker trend on natural Posidonia sinuosa leaves compared with artificial seagrass. First, sampling effort differed between the ASU and P. sinuosa components of our study. Second, samples from the distant-fromreef Site 3 clustered with sites that were located nearreef, weakening the differences between near-to- and distant-from-reef epiphyte assemblages. It is possible that this site was an outlier subject to some unusual factors influencing diversity. Removal of this site increased the strength of difference between near-toand distant-from-reef sites (from $\mathrm{R}=0.35$ to 0.56 ). Third, there may be a complex interplay of pre- and post-recruitment processes. Generally, we would expect that assemblages that differed at the recruitment stage would tend to become more dissimilar over time, unless the post-recruitment processes acted as a homogenising force. For example, grazing preferences may act (post-recruitment) to favour grazing-resistant forms such as articulated or encrusting coralline species of algae. Lavery \& Vanderklift (2002), studying seagrass epiphytes in the same region, suggested that the dissimilarity of algal epiphyte assemblages at a range of spatial scales was the result of interactions between the life-span of the seagrasses and the epiphytic algae, not just recruitment processes, and Sousa (1979), working in intertidal boulder fields, showed that post-recruitment factors, in the form of physical disturbance, caused homogenisation of periphyton assemblages on disturbed boulders while undisturbed boulders maintained the initial complexity of recruited assemblages.

\section{Can proximity to reefs explain the difference in epiphyte assemblage structure and biomass?}

The correlative results of this study indicates that proximity to reefs influences the diversity and also the biomass of epiphytes on seagrasses in adjacent meadows. Diversity of marine assemblages is related to a host of pre-recruitment and post-recruitment factors such as hydrodynamics, nutrient and light conditions, grazing and sources of propagules. If we are to explain the differences in epiphyte assemblages near-to and distant-from reefs in terms of some influence of the reef, then it is worth considering how reefs may act to 
influence those factors. While many of these factors were not explicitly measured in this study, we can speculate on how reefs could influence them in a way that creates differences in diversity and biomass.

Reef algae can be highly productive, and inputs of decomposing drift algae and other organisms to adjacent seagrass meadows may provide nutrients not available to meadows distant from a reef. In our study area, the waters are generally low in nutrients (DEP 1996), and any localised inputs from reefs would be expected to influence both biomass and, during the post-recruitment phase, species composition. Some studies have shown a positive response to nutrient enrichment by epiphyte biomass (Orth \& Van Montfrans 1984, Neckles et al. 1993) while others have not (Lin et al. 1996). Moreover, factors such as light, temperature, water motion, leaf turnover, grazing and propagule settlement interact to influence the rate at which epiphytes respond to nutrients (Neckles et al. 1993). Other studies have implicated nutrient enrichment in changes in macroalgae composition, including epiphytic macroalgae (Neckles et al. 1993, Coleman \& Burkholder 1994), and Frankovich \& Fourqurean (1997) reported shifts in species composition over the scale of tens to hundreds of metres adjacent to an island supporting bird colonies that contributed nutrients through bird defecation. Proximity to nutrient sources has been suggested as a cause of spatial patterns in the composition of epiphyte assemblages on Success Bank by Kendrick \& Burt (1997) and Lavery \& Vanderklift (2002), although these authors also acknowledge that the relationship between epiphyte biomass and nutrient availability is not a simple one.

Grazing has been implicated in variability in both the composition and biomass of epiphytic macroalgae, and could be another post-recruitment factor influenced by proximity to reefs. Alcoverro et al. (1997), studying the influence of herbivores on Posidonia oceanica epiphytes in Spain, showed that epiphyte biomass was controlled primarily by seasonal changes in seagrass shoot size, and secondarily by local environmental changes, the most important of which was herbivory. In the present experiment, artificial seagrass was used to compare biomass, so shoot size may be discounted as a potential cause of variability. Neckles et al. $(1993,1994)$ demonstrated that strong interactions between grazing and nutrients controlled epiphyte composition and biomass, with the effect of grazers being greatest. In another study, grazing on $P$. sinuosa epiphytes by amphipods reduced taxonomic richness by $12 \%$, while the absence of gastropod grazers increased biomass by $44 \%$ (Jernakoff et al. 1996). Because reefs provide different habitats, they may be a source of grazers not found in distant-from-reef seagrass meadows and may, therefore, influence the com- position of epibenthic grazers in adjacent seagrass meadows. Kirsch et al. (2002) showed that grazing on seagrasses by parrotfish emerging from adjacent reefs was common and significant, while Ogden \& Zieman (1977) and Mcintyre et al. (1987) showed that proximity to a reef influenced the intensity of grazing on adjacent seagrass by fishes. Barros et al. (2001) observed differences in benthic macrofaunal assemblages that were related to reef proximity. It is not unreasonable to speculate that proximity to a reef could influence the composition and density of epiphytic macroalgal grazers and could, therefore, have significant effects on biomass and diversity of epiphytic algae.

Water motion is also believed to affect epiphyte biomass and assemblage structure. It has been suggested that the proportion of calcifying to non-calcifying species is positively correlated with increases in current velocity and wave exposure. Kendrick et al. (1988) reported dominance of seagrass epiphyte assemblages by encrusting and articulated coralline species of algae at sites of higher current velocity. They also suggested that diversity was affected by circulation patterns that hindered dispersal of recruits, although this was at a large scale rather than the near-reef scale dealt with in our study. Other studies of epiphytes have noted differences in composition between sheltered and more exposed sites and attributed this to physical disturbance favouring coralline forms (Kendrick \& Burt 1997, Lavery \& Vanderklift 2002). Similarly, Schanz et al. (2002) found higher epiphyte biomass on Zostera noltii subjected to high-flow conditions than on specimens subjected to low-flow velocities, and attributed this to a reduction in grazers, which were unable to cope with the flow velocities. Reefs may serve as a baffle, reducing currents and swell, or the action of wave pumping may generate large currents in the immediate vicinity of reefs (Pattiaratchi et al. 1995), depending on reef aspect and the prevailing wind direction. Small-scale hydrodynamics are much more variable on and near reefs because of their complex structure (Sorokin 1993), and this may explain why epiphyte biomass at on- and near-reef sites was more variable than at distant-from-reef sites. Thus reefs may influence epiphyte assemblages of adjacent seagrass meadows at the recruitment stage by acting as a source of propagules and by influencing the dispersal of propagules, and during post-recruitment by influencing the degree of physical disturbance.

In summary, local-scale factors are the most likely causes of differences in assemblage structure of epiphytes on Posidonia sinuosa on near-reef and distantfrom-reef sites. These factors include water motion, nutrients and grazing. It is not possible to determine which particular factors produce the differences between near-reef and distant-from-reef assemblages; 
however it is probably a combination of factors acting in concert, but to varying degrees. It is reasonable to conclude that these factors are influenced by proximity to reef.

\section{Conclusions}

Our results are consistent with the notion that reefs contribute to the differences in epiphytic assemblages on seagrasses, and that proximity to reefs is one determinant of biodiversity in seagrass ecosystems. In our study, near-reef seagrass meadows contained different epiphyte assemblages than distant-from-reef meadows and artificial near-reef seagrass had a greater epiphyte biomass than distant-from-reef seagrasses. Our results suggest that propagule availability varies with distance from reefs, and the assemblages that recruit to seagrass meadows are also influenced by proximity to a reef. This highlights the potential importance of linkages among different marine ecosystems, such as reefs and seagrasses, not only for transfer of productivity but for the development and maintenance of patterns in biodiversity.

Acknowledgements. We gratefully acknowledge the assistance of Mat Vanderklift with fieldwork, algae identification and discussions of the results. Also to Helen Astill, Peter Bayliss, Sondi Bootle, Peter Poole, Amrit Work Kendrick, Mark Westera and Karen Wheeler, who all assisted with fieldwork. Also, to the anonymous reviewers who provided useful comments and suggestions, thanks.

\section{LITERATURE CITED}

Alcoverro T, Duarte CM, Romero J (1997) The influence of herbivores on Posidonia oceanica epiphytes. Aquat Bot 56: 93-104

Barros F, Underwood AJ, Lindegarth M (2001) The influence of rocky reefs on structure of benthic macrofauna in nearby soft-sediments. Estuar Coast Shelf Sci 51:191-199

Bellgrove A, Clayton MN, Quinn GP (1997) Effects of secondarily treated sewage effluent on intertidal macroalgal recruitment processes. Mar Freshw Res 48:137-146

Bold HC, Wynne MJ (1978) Introduction to the algae: structure and reproduction. Prentice Hall, Englewood Cliffs, NJ

Borowitzka MA, Lethbridge RC (1989) Seagrass epiphytes. In: Larkum AWD, McComb AJ, Shepherd SA (eds) Biology of seagrasses: a treatise on the biology of seagrasses with special reference to the Australian region. Elsevier, Amsterdam, p 459-499

Borowitzka MA, Lethbridge RC, Charlton L (1990) Species richness, spatial distribution and colonisation pattern of algal and invertebrate epiphytes on the seagrass Amphibolis griffithii. Mar Ecol Prog Ser 64: 281-291

Carr MR (1997) PRIMER user manual. Plymouth routines in multivariate ecological research. Plymouth Marine Laboratory, Plymouth, UK

Chapman MG, Underwood AJ, Skilleter GA (1995) Variability at different spatial scales between a subtidal assemblage exposed to the discharge of sewage and two control assemblages. J Exp Mar Biol Ecol 189:103-122

Clarke KR (1993) Non-parametric multivariate analyses of change in community structure. Aust J Ecol 18:117-143

Clarke KR, Warwick RM (1994) Change in marine communities: an approach to statistical analysis and interpretation. Natural Environment Research Council, Swindon, UK

Coleman VL, Burkholder JM (1994) Community structure and productivity of epiphytic microalgae on eelgrass (Zostera marina L.) under water-column nitrate enrichment. J Exp Mar Biol Ecol 179:29-48

DEP (Department of Environmental Protection) (1996) Southern metropolitan waters study (1991-1994) final report, Perth, Western Australia, November 1996. Report 17. Department of Environmental Protection, Perth

Edgar GJ, Robertson AI (1992) The influence of seagrass structure on the distribution and abundance of mobile epifauna: pattern and process in a Western Australian Amphibolis bed. J Exp Mar Biol Ecol 160:13-31

Faith DP, Minchin PR, Belbin L (1987) Compositional dissimilarity as a robust measure of ecological distance. Vegetatio 69:57-68

Frankovich TA, Fourqurean JW (1997) Seagrass epiphyte loads along a nutrient availability gradient, Florida Bay, USA. Mar Ecol Prog Ser 159:37-50

Hillman K, Morrison PF, Jernakoff P, Nielson J (1994) Perth coastal waters study: determination of time series changes in marine communities, Project E2. Water Authority of Western Australia, Leederville

Hoffmann AJ (1987) The arrival of seaweed propagules at the shore: a review. Bot Mar 30:151-165

Horner SMJ (1987) Similarity of epiphyte biomass distribution on Posidonia and artificial seagrass leaves. Aquat Bot 27: 159-167

Huisman J, Walker D (1990) A catalogue of marine plants of Rottnest Island, Western Australia, with notes on their distribution and biogeography. Kingia 1:349-459

Jernakoff P, Brearley A, Nielsen J (1996) Factors affecting grazer-epiphyte interactions in temperate seagrass meadows. Oceanogr Mar Biol Annu Rev 34:109-162

Kendrick GA (1991) Recruitment of coralline crusts and filamentous turf algae in the Galapagos archipelago: effect of simulated scour, erosion and accretion. J Exp Mar Biol Ecol 147:47-63

Kendrick GA, Burt JS (1997) Seasonal changes in epiphytic macro-algae assemblages between offshore exposed and inshore protected Posidonia sinuosa Cambridge et Kuo seagrass meadows, Western Australia. Bot Mar 40:77-85

Kendrick GA, Hawkes MW (1988) The epiphyte Microcladia coulteri (Rhodophyta): changes in population structure with spatial and temporal variation in availability of host species. Mar Ecol Prog Ser 43: 79-86.

Kendrick GA, Lavery PS (2001) Assessing biomass, assemblage structure and production of algal epiphytes on seagrasses. In: Short FT, Coles RG (eds) Global seagrass research methods. Elsevier Science, Amsterdam, p 199-222

Kendrick GA, Walker DI (1995) Dispersal of propagules of Sargassum spp. (Sargassaceae: Phaeophyta): observations of local patterns of dispersal and consequences for recruitment and population structure. J Exp Mar Biol Ecol 192:273-288

Kendrick GA, Walker DI, McComb AJ (1988) Changes in distribution of macro-algal epiphytes on stems of the seagrass Amphibolis antarctica along a salinity gradient in Shark Bay, Western Australia. Phycologia 27:201-208

Kendrick GA, Hegge BJ, Wyllie A, Davidson A, Lord DA (2000) Changes in seagrass cover on Success and Parmelia 
Banks, Western Australia between 1965 and 1995. Estuar Coast Shelf Sci 50:341-353

Kirsch KD, Valentine JF, Heck KL Jr (2002) Parrotfish grazing on Thalassia testudinum: evidence for the importance of seagrass consumption in food web dynamics of the Florida Keys National Marine Sanctuary. Mar Ecol Prog Ser 227: 71-85

Kitting CL, Fry B, Morgan MD (1984) Detection of inconspicuous epiphytic algae supporting food webs in seagrass meadows. Oecologia 62:145-149

Lavery PS, Vanderklift MA (2002) A comparison of spatial and temporal patterns in epiphytic algae assemblages of the seagrasses Amphibolis griffithii and Posidonia coriacea. Mar Ecol Prog Ser 236:99-112

Lin HJ, Nixon SW, Taylor DI, Granger, SL, Buckley BA (1996) Response of epiphytes on eelgrass, Zostera marina L., to separate and combined nitrogen and phosphorus enrichment. Aquat Bot 52:243-258

Marbà N, Walker DI (1999) Growth, flowering, and population dynamics of temperate Western Australian seagrasses. Mar Ecol Prog Ser 184:105-118

Mcintyre IG, Graus RR, Reinthal PN, Littler MM, Littler DS (1987) The Barrier Reef sediment apron: Tobacco Reef, Belize. Coral Reefs 6:1-12

Neckles HA, Wetzel RL, Orth RJ (1993) Relative effects of nutrient enrichment and grazing on epiphyte-macrophyte (Zostera marina L.) dynamics. Oecologia 93:285-295

Neckles HA, Koepfler ET, Hass LW, Wetzel RL, Orth RJ (1994) Dynamics of epiphytic photoautotrophs and heterotrophs in Zostera marina (eelgrass) microcosms: responses to nutrient enrichment and grazing. Estuaries17:597-605

Ogden JC, Zieman JC (1977) Ecological aspects of coral reef-seagrass bed contacts in the Caribbean. Proc 3rd Int Coral Reef Symp, p 377-382

Orth RJ, Van Montfrans J (1984) Epiphyte-seagrass relationships with an emphasis on the role of micrograzing: a

Editorial responsibility: Kenneth Heck (Contributing Editor), Dauphin Island, Alabama, USA review. Aquat Bot 18:43-69

Pattiaratchi C, Imberger J, Zaker N, Svenson T (1995) Perth coastal waters study: physical measurements project P2. Water Authority of Western Australia, Leederville

Pinckney JL, Micheli F (1999) Microalgae on seagrass mimics: does epiphyte community structure differ from live seagrasses. J Exp Mar Biol Ecol 221:59-70

Schanz A, Polte P, Asmus H (2002) Cascading effects of hydrodynamics on an epiphyte-grazer system in intertidal seagrass beds of the Wadden Sea. Mar Biol 141:287-297

Sokal RR, Rohlf FJ (1981) Biometry: the principles and practice of statistics in biological research, 2nd edn. WH Freeman, New York

Sorokin YI (1993) Coral reef ecology. Springer-Verlag, Berlin

Sousa WP (1979) Disturbance in marine inter-tidal boulder fields: the cross-equilibrium maintenance of species diversity. Ecololgy 60:1225-1239

Vanderklift MA, Lavery PS (2000) Patchiness in assemblages of epiphytic macroalgae on Posidonia coriacea at a hierarchy of spatial scales. Mar Ecol Prog Ser 192: $127-135$

West RJ (1990) Depth-related structural and morphological variations in an Australian Posidonia seagrass bed. Aquat Bot 36:153-166

Womersley HBS (1984) The marine benthic flora of Southern Australia, Part I. South Australian Government Printing Division, Adelaide

Womersley HBS (1987) The marine benthic flora of Southern Australia, Part II. South Australian Government Printing Division, Adelaide

Womersley HBS (1994) The marine benthic flora of Southern Australia, Part IIIA. South Australian Government Printing Division, Adelaide

Womersley HBS (1996) The marine benthic flora of Southern Australia, Part IIIB. South Australian Government Printing Division, Adelaide

Submitted: November 22, 2003; Accepted: April 12, 2004 Proofs received from author(s): July 21, 2004 